\title{
RESEARCH AND CREATIONS BETWEEN ART-ARCHITECTURE \\ TO ENHANCE THE URBAN HERITAGE THROUGH AN \\ EDUCATIONAL PROCESS
}

\author{
Alessandra De Nicola \\ Università di Milano-Bicocca, Universidad Católica San Antonio de Murcia
}

\section{María Eugenia García-Sottile}

Universidad Católica de Valencia

\section{Sebastián Gómez-Lozano}

Universidad Católica San Antonio de Murcia

\begin{abstract}
This contribution describes an action research project, the result of which was the industrial production of a cultural heritage interpretation 500 kit based on the contamination of languages and disciplines. The object of the research was the methods of mediation and interpretation of heritage to activate a process of co-construction with all traceable stakeholders. The new traced knowledge became the contents of the kit, reaching which it was necessary to establish collaboration between disciplines, researchers and practitioners. Starting from the change in the paradigm of heritage fruition that generally sees the cultural object as a protagonist and the community as a recipient, it will be shown how interdisciplinary dialogue has created a virtuous circle between community, heritage and new recipients of fruitive action. In particular, it will show how there has been a profitable exchange between body, sound and vision education and education in cultural heritage and Renaissance urban architectural values.
\end{abstract}

Keywords: HERITAGE EDUCATION; RESEARCH AND CREATIONS BETWEEN ARTARCHITECTURE

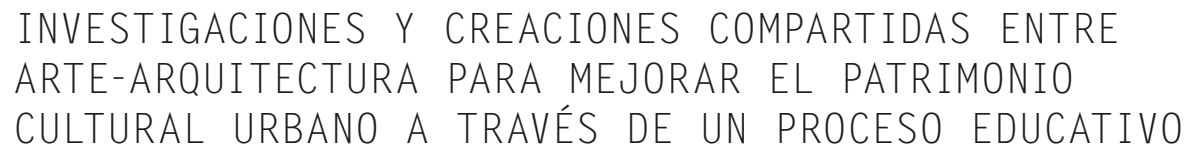

\section{Resumen}

En esta contribución se describe un proyecto de investigación-acción, cuyo resultado fue la producción industrial de un kit (500 piezas) de interpretación del patrimonio cultural basado en la contaminación de diferentes disciplinas. El objeto de la investigación fueron los métodos de mediación e interpretación del patrimonio para activar un proceso de co-construcción con todas las partes involucradas. Los nuevos conocimientos obtenidos se convirtieron en el contenido del kit, para lograrlo fue necesario activar la colaboración entre las disciplinas, los investigadores y los profesionales. A partir del cambio de paradigma de fruición del patrimonio que normalmente ve al objeto cultural como protagonista y a la comunidad como receptora, se mostrará que el diálogo interdisciplinar ha creado un círculo virtuoso entre la comunidad, el patrimonio y los nuevos receptores de esta acción. En particular, mostrará cómo ha habido un intercambio provechoso entre la educación corporal (expresión corporal), sonora, visual y la educación al patrimonio cultural y de los valores arquitectónicos y urbanísticos del Renacimiento

\section{Palabras clave: EDUCACIÓN SOBRE EL PATRIMONIO; INVESTIGACIÓN Y CREA- CIONES ENTRE ARQUITECTURA DE ARTE}

De Nicola, Alessandra, María Eugenia Garcia Sotile \& Sebastián Gómez Lozano. 2020. "Research and creations between art-architecture to enhance the urban heritage through an educational process". AusArt 8 (2): 25-37. D0I: 10.1387 /ausart.22105

\section{AUSART}




\section{INTRODUCTION}

This contribution describes an action research project, carried out between 2017 and 2020, which found in the contamination between languages and disciplines, the answer to a concrete problem expressed by local administrations, first depositing local assets and responsible for the management and use policies. Therefore, we have the ambition to respond through a case study to the questions expressed in this monograph. The case study took place in the cities of Mantua and Sabbioneta, in northern Italy. These are two distinct cities that have been designated by UNESCO as the only World Heritage Site. After a decade of educational and enhancement initiatives, the two administrations and the UNESCO office found that citizens did not perceive the heritage value of the places of their everyday life and did not feel any commonality with the other city. This situation also had repercussions on tourism proposals.

The research group involved thus decided to create a kit, a set of tools for the fruition and interpretation of cities, based on a co-construction path of knowledge, whose aim was to educate people about heritage, involving them in the valorization process. We worked with the primary objective of engaging the largest number of stakeholders: schools of all levels, teachers, experts, professionals, pensioners, administrators, politicians, day centres for the treatment of mental disabilities. The languages chosen to define the proposed contents and activities belong to the fields of visual arts, soundscapes, body education, architecture and botany. In homage to the historical context in which the two cities have developed although at different times and with diverse aims, we can say that the choice of disciplines brings back to the objective of a 'total' education proper to humanistic pedagogy, theorized by Pier Paolo Vergerio [14001402] in De ingenuis moribus et liberalis studii adulescentiae liber (Frasca 1993), enriched and made famous through Michel de Montaigne's essays on education (1580). According to the French philosopher, the choice of the field of action had the objective of combining body and soul, associating disciplines distant from each other, to overcome some barriers of access to cultural heritage through a sensitive approach. 


\section{MANTUA AND SABBIONETA UNESCO WORLD HERITAGE SITE}

The reasons for inclusion of Mantua and Sabbioneta in the Unesco list, has guided the definition of the disciplinary field of the project. Mantua and Sabbioneta have been on the UNESCO World Heritage List since 2008 because they are exceptional examples of the two principal urban forms of the Renaissance: Sabbioneta is a newly founded city, based on the concept of the ideal city; Mantua is an older foundation city that has been transformed over time. The visible sources of this history can be found in its architecture, technological elements and monumental art. The two cities are evidence of a civilization linked to a specific historical period, which has had reflections in the fields of urban planning, architecture and fine arts. "The ideals of the Renaissance, supported by the Gonzaga family, are present in their architecture and urban morphology, in their functional system and in their traditional productive activities, which are mostly preserved over time"1.

\section{THE KIT- AN ACT OF CONTEMPORARY CULTURAL PRODUCTION}

The peculiarity of the kit is that it can be used without the need for a formal guide, but at the same time it allows to propose workshop activities managed by teachers and skilled operators. The tools developed allow reading and comprehension at different levels of competence to satisfy these requirements: from children accompanied by their families to connoisseurs, up to explorers by chance, with due care to the various skills.

It was an act of contemporary cultural production, in which the process was as valuable as the final result. The idea that the path is educatively more relevant than the output is a concept of empirical teaching methods (Rousseau, Dewey, Weyland...), which in this case is brought back to a different context. At the same time, this principle defines a large part of contemporary cultural production in the artistic and performative field and it marks the participatory relationship with the public (Robertshaw 2006; Bal 2011; Jackson \& Kidd 2011).

For the audiences involved during the research, the outcome of the kit represented only a point of arrival. What allowed to trigger the process of belonging 
and a real recognition of one's cultural heritage was the moment in which the contents were identified with the public and through workshop type solicitations deriving from the different disciplinary areas.

This has led to a change in the paradigm of cultural heritage enhancement. We started from the community that acted within the reference landscape, understood as a real identity horizon (De Nicola 2016) to find the most appropriate form of a collective discourse on the restitution of cultural objects, in this case, the city's heritage.

The first stage of the journey was to bring out the public's gaze through two different approaches, one autobiographical (Cambi, Demetrio, Mancino) and the other interpretative (Tilden, Hooper Greenhil, Volli). Concerning the first approach, we worked on the personal experience: with interviews, maps and stories through images, thanks to which we built a mosaic of autobiographical content that allowed us to identify the really significant elements for the different communities. The tool of the kit that best sums up this process visually are the maps of the two cities (see fig 1). As far as the interpretative approach is concerned, we worked in a laboratory way, proposing activities of: sound landscape education with the musician Federica Furlani, body exploration with the pedagogist and performing arts expert Giulia Schiavone and architectural exploration with the architect Patrizia Berera. In this case we had a twofold objective: to check out some of the proposals for activities that formed part of the kit; to research the points of view of the public through unusual approaches to cultural heritage.

Fig. 1- The map of Sabbioneta, with interactive stories by community, architectural and musical tools.

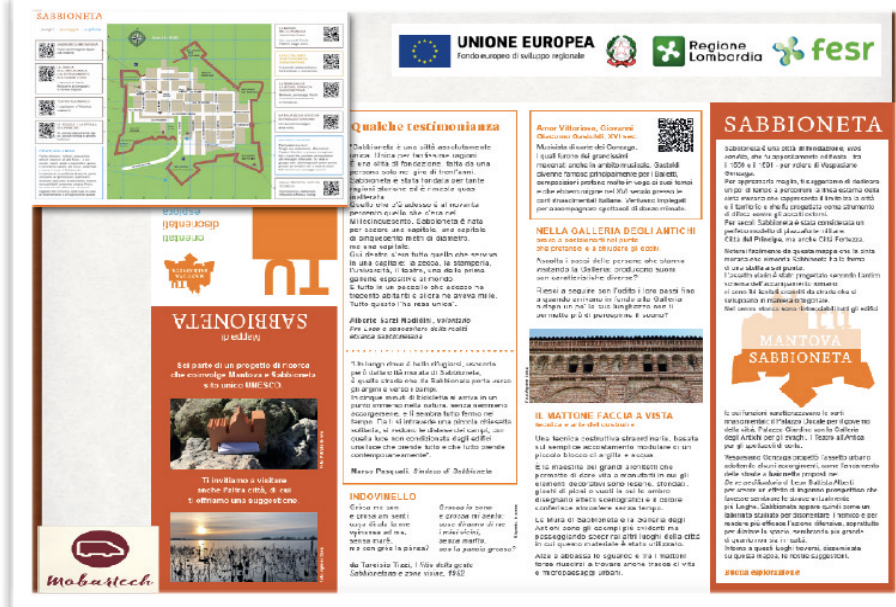




\section{A LITTLE MORE SPECIFICALLY}

\section{BODY EXPLORATIONS}

In this case, the aim was to deepen the link between performing arts and urban landscape (Metta \& Di Donato 2014). The theoretical background we started from can be found in the work of Metta and Di Donato book, about the performative projects developed by Anna and Lawrence Halrpin, in which the authors underline how the body movement is a very valuable form of knowledge, activation and configuration of space. Precisely in line with what empiricist theorists have indicated, the experience of the urban context patrimonialized through the body offers the opportunity to understand it through an observation that does not only pass through the eye. The assumption from which Metta and Di Donato start is that "space is also built by the person's movement [...]. Movements become flows [...], signs that affect the physical configuration of the place" $(2014,34)$. In this sense, the solicitation is that of living public spaces not as static and complete configurations but, on the contrary, "as welcoming places for the unexpected [...], as playful machines that continuously [...] invite everyone to dance their own dance or all together with the same score" (35), involving the community as an active agent.

The idea of developing interaction between a group of individuals and the place, and consequently bringing this back to a large community through the creation of 'human architecture', comes from the project Experiments in Environment, by American landscape architect Lawrence Halprin and dancer, teacher and choreographer Anna Schuman Halprin between 1968 and 1971 in San Francisco and along the coast of northern California. As in the American case, also marked by a cross-disciplinary approach, the bodies were conceived as spatial devices in reciprocal equilibrium, to amplify involvement with the urban landscape, to develop an attitude of listening and self-awareness concerning the place (see fig. 2). The exploration of the two cities with these interpretative tools was carried out with primary and secondary school students. Primary and secondary school students had participated in these kinds of exploration. During the process, each participant was asked to reflect on his or her way of dealing with heritage. The invitation to interpret the landscape or its objects through a perception more focused on cultural and spatial elements, 'physical encumbrances of lived space', usually concealed by the veil of everyday life, led to a new awareness, as the words of the students met testify: "The gesture of telling the experience allows one to relate to the way one lives the visit" (February 2020). "Today I noticed some frescoes [bas-reliefs on the external wall 
of Palazzo Te] that I had never seen before, and that one of the companions imitated" (January 2020). And again, "the action of imitating leads one to focus attention on details, to see well" (January, February 2020).

A notebook of suggestions and activity proposals left as a gift to each user of the kit (see fig. 3,4$)$ make visible the results of this type of approach.
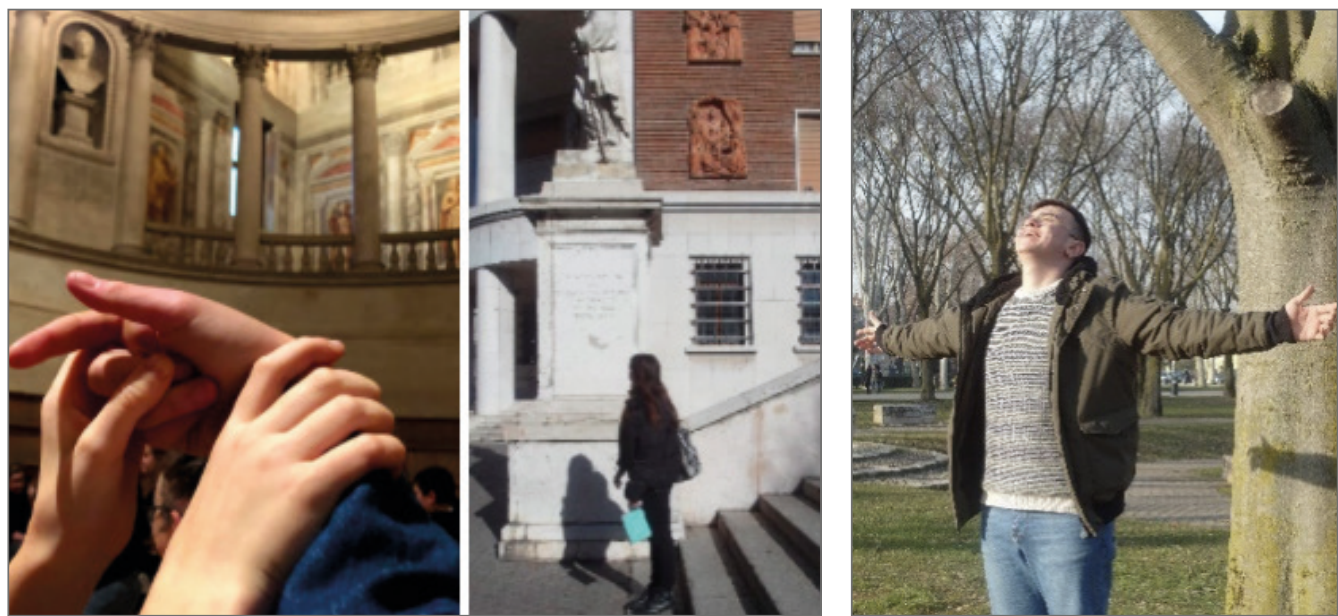

fig.2- Images from the workshop: playing with the statue and the sculptor;observing the shadow greet the city and express a gesture of gratitude. Credit: 1. Alessandra De Nicola, 2/3 Giulia Schiavone.
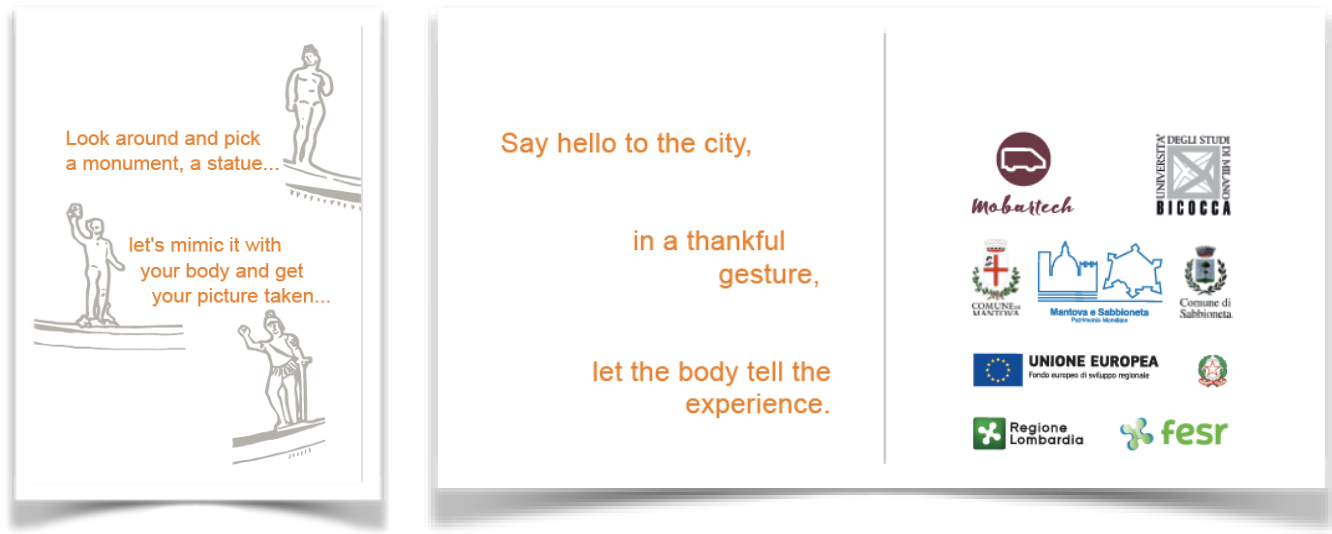

fig.3- pages from the notebook: some activity proposals between body, art and architecture. 


\section{SOUND EXPLORATIONS}

This type of exploration has worked on improving listening skills to benefit from the intangible sound heritage, and to use sound in turn as a tool for knowledge and interpretation of the cultural heritage as a whole. One of the theoretical boundaries adopted is determined by the research of Ecosofia del paesaggio (Ecosophy of the landscape) theorized by Barbanti according to which sound determines a "relationship rich in teachings. The sound, in fact, unfolding in time, gives itself to the listener only in a relationship of coexistence, of coexistence, of existential coincidence with itself. Contrary to objects, which remain despite our gaze, sounds require a sort of submission to their temporality. [...] We cannot experience sound without being present and subject to sound itself, and its teachings are exemplary. [...] Listening can provide us with reference and structuring elements of a new cognitive mode. Our civilization, the expression of a retinal paradigm and its zealous propagator and imposter, needs real alternatives to its instrumental view. [...] Landscape is a global aesthetic experience and listening to it is fondant and fundamental aspect" (Barbanti 2015, 74-8).

To achieve these objectives and to give as immediate access as possible to all levels of knowledge, we have chosen to emphasize sound mediation than to musical mediation. The aim was that the visitor or citizen should understand the surrounding sound heritage. In contemporary society strongly influenced by visual culture, in which sight has a series of tools for data collection and interpretation, hearing is a less developed sense. Since, as Murray Schafer says, man cannot but hear "the sense of hearing cannot be closed at will. The ear has no eyelids" $(1985,24)$.

This work has intended to treat intentional listening to generate an attentive and analytical perceptive practice. An attempt was made to encourage a general approach to the sensory activations proposed, to achieve a 'basic' level of listening awareness, such as to bring the visitor closer to any sound heritage (and also preparatory to musical stimulation). Alongside this proposal, activities have been indicated to trace the specific identity of the sites under examination. If for Mantua the stimulations were focused on finding a sound identity for a very dense acoustic environment, for Sabbioneta they tried to live with the sound of empty and silent spaces. Sabbioneta, in fact, a 16th-century city of foundation, presents a unique acoustic environment. The historical city center is inhabited by a population of about three hundred people; this means that silence is the predominant element of this sound landscape. 
The result of these explorations, which have been included in the notebook (fig.4), was the result of various experiments with adolescents, adults and people with mental health difficulties. In all cases, the result was a sense of pleasant discovery, towards elements normally neglected. In particular, the youngsters, whose first sensibility was towards a sound ecology, aimed at eliminating background noises, felt the desire to continue autonomously taking advantage of the newly acquired cognitive tools and carrying out explorations around their homes. The element unexpected by the researchers was personal restitution of their sonic habitat.

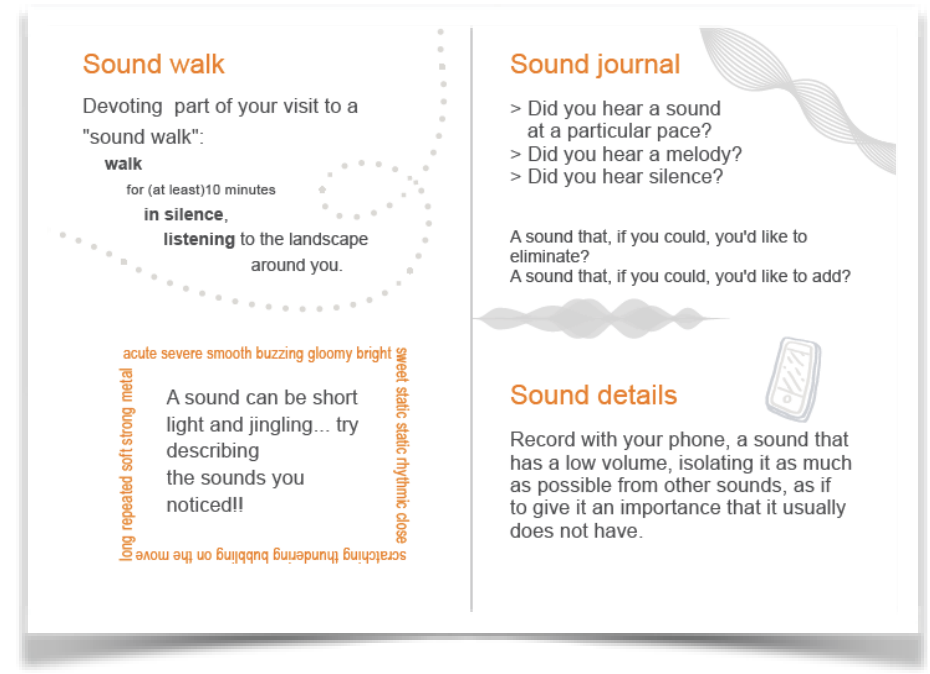

Fig.4- pages from the notebook notebook: sound explorations

\section{EXPLORATIONS BETWEEN ART AND ARCHITECTURE}

This part aimed to highlight the Renaissance values that typify the buildings and the urban planning of the two cities. In particular, this was one of the aspects that most clearly could show the link between the two cities. It's relevant to show that they have two specific feature: since its foundation, Mantua has continued to change over time, this is visible from the toponymy, while Sabbioneta has remained substantially unchanged. From the observation of the architectural elements, the aim was to make it understandable what it meant in 2020 to say that Sabbioneta is an ideal city. To reach this purpose, we developed activities: strongly linked to drawing, to a narrative aimed at reflecting on the past and the future, to a search of balance and symmetries (in synergy with the activities 
described above); also activities with a highly creative expressive slant such as the mandala map, which sees the overlapping of the maps of the two cities with the invitation to decorate them to one's taste as an exercise in the practice of mandalas (fig.5). Among the tools in the kit, there is a handbag mirror, through which it is possible to verify the symmetries, to observe the frescoes on the ceilings without having to change one's posture. This is to induce users to constantly change their point of view, passing through tactile, visual, postural and action aspects. Among the tools in the kit, there is a handbag mirror, through which it is possible to verify the symmetries, to observe the frescoes on the ceilings without having to change one's posture. This is to induce users to continuously change their point of view, passing through tactile, visual, postural and action aspects.
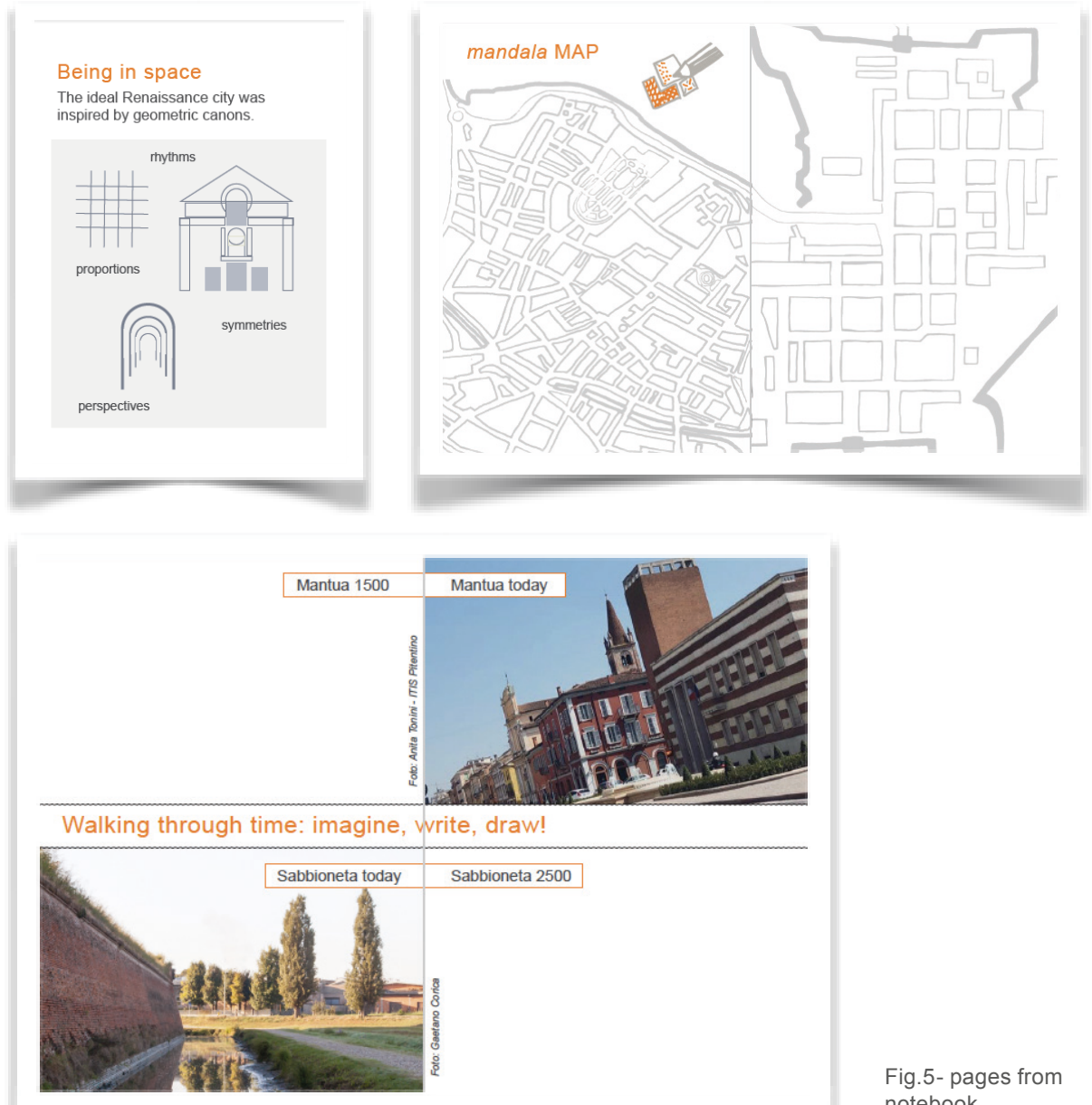

Fig.5- pages from notebook 


\section{CONCLUSION}

The work described here tells of a change in the paradigm of mediation and heritage education through collaboration between different disciplines.

Precisely from this innovation emerged the critical points that have determined our challenge:

- The enhancement of an extensive heritage that is not limited to the cultural function alone.

- So many actors involved with as many interests and needs for which we need to find multiple responses and as little standardized as possible.

- Two living cities, distant from each other from many points of view, yet united from a cultural point of view.

Facing these challenges in the ways described has challenged the definition of cultural heritage: no longer the collection of goods and practices identified and valued by a small circle of professionals, but the set of identity symbols selected by citizens and validated, studied, made as accessible as possible to the general public through the work of professionals. It was a cooperative process between a team with different skills and communities.

Practitioners and academic researchers first of all investigated and developed useful materials to collect autobiographical content, based on which we studied the historical, artistic and visual fields. The intention was to open up a dialogue between individuals and environments, asking first of all to "really see them, but also to rethink them and to rethink how they canbe brought togheter" (Guerra \& Ottolini 2019, 19).

The images, photographs and, more generally, the equipment identified for the composition of the kit (all strongly connoted by a visual aspect, such as to make an immediate reading and comprehension of the contents), exactly as had happened with landscape painting and then with postcards, intervene to build a new form of representation (Borgherini \& Sicard 2020). New because it is the result of a collective narration that sees the overturning of the paradigm of the fruition of cultural heritage in which the object, the cultural good was not the end and beginning of the fruitive action, but the pretext for an exercise of interpretation that starts from those who live a place every day, invests the object with meaning and builds a "community of interpretation" around it 
(Hooper-Greenhill 2003). The cultural object can thus be read in different ways according to the social meaning attributed to it. This kind of reading is accompanied by the attention, as educators and pedagogues, to favour a process of growth and transformation (Mortari 2003), which starts from the search for the possibilities of promoting reflections and experiences aimed at living the cultural heritage, not only through a rational-intellective kind of knowledge but also through a sensitive one.

This is because, as Le Breton (2007) states, sensory perceptions combine with meanings, delineating the boundaries perceived as vague of the environments lived, defining them better and giving them more meaning.

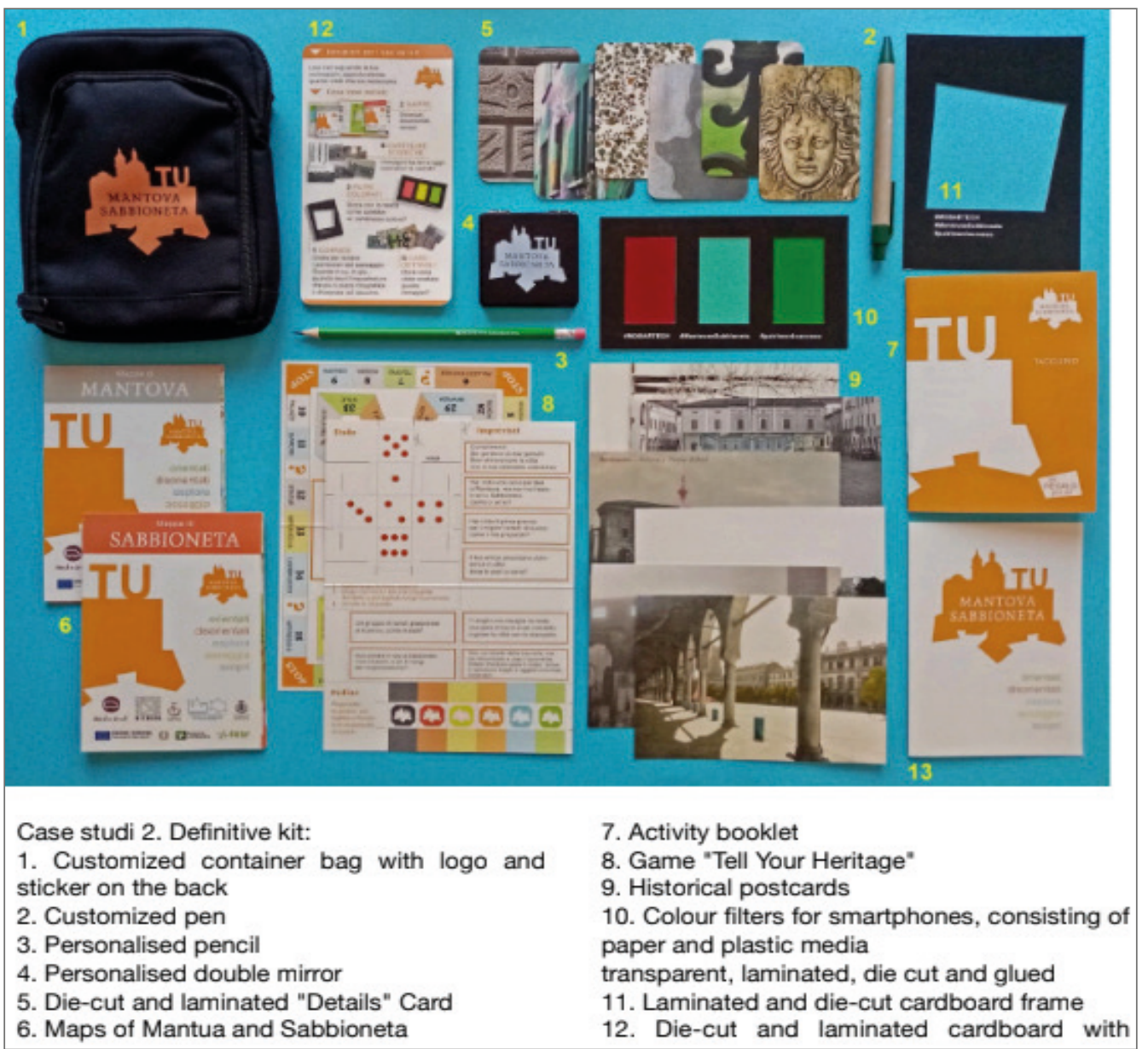




\section{References}

Bal, Mieke. 2011. "Exposing the public". In A companion to museum studies, edited by Sharon Macdonald, 525-42. Malden MA: Oxford Blackwell

Barbanti, Roberto. 2015. "Ecosofia sonora: Per un ascolto del paesaggio e del mondo". In II suono percepito, il suono raccontato: Paesaggi sonori in prospettiva multidisciplinare, a cura di Alessandra Calanchi, 61-84. Teramo: Galaad

Borgherini, Malvina \& Monque Sicard. 2020. Photopaysage; Il paesaggio inventato dalla fotografia. Macerata: Quodlibet

Cambi, Franco. 2002. L' autobiografia come metodo formativo. Bari: Laterza

De Nicola, Alessandra. 2016. "Arte e Scienza: Non è bello ciò che è bello, ma è bello ciò che capisco". In Paesaggi culturali: Nuove forme di valorizzazione del patrimonio; Dalla ricerca all'azione condivisa, Alessandra De Nicola \& Franca Zuccoli, eds. Sant'Arcangelo di Romagna: Maggioli

Frasca, Rosella. 1993. "Pietro Polo Vergerio Giustinopolitano ad Ubertino da Carrara: II comportamento corretto e l'educazione liberale degli adolescenti. Tattatello in due parti“. Rassegna di Pedagogia 1(1-2): 19-53

Guerra, Monica \& Lola Ottolini. 2019. In strada: Azioni partecipate in spazi pubblici. Mantova: Corraini

Hooper Greenhill, Eilean. 2003. "Evoluzione dei modelli comunicativi nei musei d'arte". In II museo relazionale: Riflessioni ed esperienze europee, a cura di Simona Bodo, 1-40. Torino: Fondazione Giovanni Agnelli

Jackson, Anthony \& Jenny Kidd, eds. 2011. Performing heritage: Research, practice and innovation in museum theatre and live interpretation. Manchester: Manchester University

Le Breton, David. 2007. I/ sapore del mondo: Un'antropologia dei sensi. Milano: Raffaello Cortina

Mancino, Emanuela. 2014. A perdita d'occhio: Riposare lo sguardo per una pedagogia del senso sospeso. Milano: Mursia

Metta, Annalisa \& Benedetta Di Donato. 2014. Anna e Lawrence Halprin: Paesaggi e coreografie del quotidiano. Melfi: Libria

Montaigne, Michel de. (1580) 2007. Saggi. A cura di Fausta Gravini. Milano: Adelphi

Mortari, Luigina. 2003. Apprendere dall'esperienza: Il pensiero riflessivo nella formazione. Roma: Carocci

Norberg-Schulz, Christian. 2011. Genius loci: Paesaggio ambiente architettura. Milano: Mondadori Electa

Robertshaw, August. 2006. "Live interpretation". In Heritage interpretation, edited by Alison Hems \& Marion Blockley, 41-54. London: Routledge

Schafer, Murray R. 1985. II paesaggio sonoro. Traduzione di Nemesio Ala. Milano: Ricordi LIM

Tilden, Freeman. 1957. Interpreting our heritage. Chapel Hill NC: University of North Carolina

Volli, Ugo. 2008. Lezioni di filosofia della comunicazione. Bari: Laterza

Weyland, Beate Christine. 2017. Didattica sensoriale: Oggetti e materiali tra educazione e design. Milano: Guerini 


\section{Notes}

${ }^{1}$ https://whc.unesco.org/en/list/1287/

(Artículo recibido: 04-10-20; aceptado: 27-11-20) 